\title{
Measurement report: Large contribution of biomass burning and aqueous-phase processes to the wintertime secondary organic aerosol formation in Xi'an, Northwest China
}

Jing Duan ${ }^{1}$, Ru-Jin Huang ${ }^{1,2}$, Yifang $\mathrm{Gu}^{1,2}$, Chunshui Lin ${ }^{1}$, Haobin Zhong ${ }^{1,2}$, Wei Xu ${ }^{1}$, Quan Liu ${ }^{3}$, Yan You $^{4}$, Jurgita Ovadnevaite ${ }^{5}$, Darius Ceburnis ${ }^{5}$, Thorsten Hoffmann ${ }^{6}$, Colin O’ Dowd ${ }^{5}$

${ }^{1}$ State Key Laboratory of Loess and Quaternary Geology (SKLLQG), CAS Center for Excellence in Quaternary Science and Global Change, Institute of Earth Environment, Chinese Academy of Sciences, Xi'an 710061, China

${ }^{2}$ University of Chinese Academy of Sciences, Beijing 100049, China

$10{ }^{3}$ China State Key Laboratory of Severe Weather \& Key Laboratory of Atmospheric Chemistry of CMA, Chinese Academy of Meteorological Sciences, Beijing 100081, China

${ }^{4}$ National Observation and Research Station of Coastal Ecological Environments in Macao, Macao Environmental Research Institute, Macau University of Science and Technology, Macao SAR 999078, China

$15{ }^{5}$ School of Physics and Centre for Climate and Air Pollution Studies, Ryan Institute, National University of Ireland Galway, University Road, Galway, H91CF50, Ireland

${ }^{6}$ Department of Chemistry, Johannes Gutenberg University Mainz, Duesbergweg 10-14, Mainz 55128, Germany

Correspondence: Ru-Jin Huang (rujin.huang@ieecas.cn) or Quan Liu (liuq@cma.gov.cn)

20 Abstract

Secondary organic aerosol (SOA) plays an important role in particulate air pollution, but its formation mechanism is still not fully understood. The chemical composition of non-refractory particulate matter with a diameter $\leq 2.5 \mu \mathrm{m}\left(\mathrm{NR}-\mathrm{PM}_{2.5}\right)$, OA sources, and SOA formation mechanisms were investigated in urban Xi'an during winter 2018. The fractional contribution of SOA to total OA mass (58\%) was larger than primary OA (POA, 42\%). A biomass burning-influenced oxygenated OA (OOA-BB) was resolved in urban Xi'an, which was formed from the photochemical oxidation and aging of biomass burning OA (BBOA). The formation of OOA-BB was more favorable in the days with larger OA fraction and higher BBOA concentration. In comparison, the aqueous-phase processed oxygenated OA (aq-OOA) was more dependent on secondary inorganic aerosol (SIA) content and aerosol liquid water

30 content (ALWC), and increased largely to 50\% of OA during SIA-enhanced periods. Further Van Krevelen (VK) diagram analysis suggests the increased aq-OOA contributions during SIA-enhanced periods were likely from alcohol or peroxide addition in the OA aqueous-phase oxidation processes.

\section{Introduction}

Particulate matter with a diameter $\leq 2.5 \mu \mathrm{m}\left(\mathrm{PM}_{2.5}\right)$ in the atmosphere has become an important environmental problem for climate, visibility and human health, especially in China with rapid 
industrialization, urbanization and population expansion (Huang et al., 2014; Lelieveld et al., 2015; Peng et al., 2016; An et al., 2019). Most megacities in China are frequently plagued by severe particulate pollution in recent years, attracting extensive attention and research on its composition characteristics and formation mechanisms (Guo et al., 2014; Hu et al., 2013, 2016; Li et al., 2017; Tong et al., 2017; Sun et al., 2016, 2018). The haze pollution occurs more frequently in winter with unfavorable meteorological conditions, and myriad variables, such as complex emission sources, pollutant lifetimes, and atmospheric reactions (Sun et al., 2013, 2014; Elser et al., 2016; Hu et al., 2016; An et al., 2019; Kuang et al., 2020).

Fine particles can be either emitted directly from primary sources that refers to as primary aerosol, or produced in the atmosphere through gas-to-particle conversion or aging of primary aerosol, which refers to as secondary aerosol (Jimenez et al., 2009; Liu et al., 2010; Xu et al., 2017). Numerous studies have elucidated the increasing importance of secondary aerosol in haze pollution (Sun et al., 2016; Huang et al., 2014, 2019; An et al., 2019; Duan et al., 2020). However, the formation and evolution of secondary aerosol, especially secondary organic aerosol (SOA), is still not well understood and becoming a critical concern for air pollution research (Gilardoni et al., 2016; Xu et al., 2017; Kuang et al., 2020). Variable precursors, complex transformation and aging chemistry of SOA lead to insufficient cognition of its formation and uncertainty in model simulation (Shrivastava et al., 2017).

Field studies based on aerosol mass spectrometer (AMS) combined with OA source apportionment techniques (Paatero, 1999; DeCarlo et al., 2006; Canonaco et al., 2013) have been conducted in China to resolve SOA sources and investigate its formation and evolution mechanisms (Hu et al., 2013, 2016; Sun et al., 2016; Xu et al., 2017, 2019). Gas-phase photochemical oxidation has been considered as a major pathway of SOA formation in a number of studies, according to the correlation between SOA and odd oxygen ( $\mathrm{Ox}=\mathrm{O}_{3}+\mathrm{NO}_{2}$ ) (Sun et al., 2014; Elser et al., 2016; Hu et al., 2016). However, recent studies also revealed the important contribution of aqueous-phase chemistry to SOA formation, which

60 is also missing in SOA simulation (Guo et al., 2014; Sun et al., 2016; Xu et al., 2017, 2019; Huang et al., 2020). For example, Sun et al. (2016) resolved an aqueous-phase-processed SOA (aq-OOA) which significantly affected OA oxidation state in high RH conditions ( $>50 \%)$. The results of Wang et al (2017) and Xu et al. (2017) indicated that aqueous-phase chemistry played a dominant role in the formation of more-oxidized-oxygenated OA (MO-OOA). Kuang et al. (2020) further resolved the contribution of

65 photochemical aqueous-phase chemistry in wintertime haze pollution which induced the rapid formation of SOA in the daytime.

As the largest city of the Guanzhong basin, one of the top three regions in China's air cleaning campaign, $\mathrm{Xi}$ 'an has suffered serious particulate pollution in recent years due to the rapid urbanization, while research on aerosol composition and SOA formation mechanisms are still limited (Elser et al., 2016;

70 Zhong et al., 2020; Duan et al., 2021). Elser et al (2016) analyzed the chemical composition and OA sources of $\mathrm{PM}_{2.5}$ during the heavy pollution period of 2013 in Xi'an using a high resolution AMS (HRAMS), and found the contribution of SOA increased during extreme haze events, but the SOA formation 
mechanism and OA oxidation state during haze pollution were not well analyzed. As multiple control measures have been implemented in Xi' an, such as the 13th five-year energy conservation and emission reduction plan, and motor vehicle restrictions, it is expected that aerosol composition and sources have largely varied in recent years, while direct elucidation and characterization are lack.

In this study, $\mathrm{PM}_{2.5}$ composition was measured during the heating season of 2018 in $\mathrm{Xi}$ ' an using a soot particle long-time-of-flight AMS (SP-LToF-AMS). Chemical composition and OA sources were analyzed and compared with those resolved in Elser et al (2016), in order to elucidate the aerosol variation in recent years due to emission controls. Meanwhile, the SOA formation mechanisms and its contribution to haze event were investigated and compared with those in the summer of 2019 (Duan et al., 2021).

\section{Experimental}

\subsection{Sampling}

85 The winter campaign was conducted from $4^{\text {th }}$ December 2018 to $15^{\text {th }}$ March 2019 at the campus of the Institute of Earth Environment, Chinese Academy of Sciences $\left(34^{\circ} 23^{\prime} \mathrm{N}, 108^{\circ} 89^{\prime}, 12 \mathrm{~m}\right.$ above the ground level) in downtown Xi' an with surrounding residential, commercial, and traffic areas (Duan et al., 2021).

A SP-LToF-AMS (Aerodyne Research Inc.) was deployed for the online characterization of $\mathrm{PM}_{2.5}$ with

90 a time resolution of $1 \mathrm{~min}$. The detailed instrument description could be found in Onasch et al. (2012) and a similar operation was conducted as that in Duan et al. (2021). The contribution of black carbon (BC) was not considered, and only NR-PM ${ }_{2.5}$ composition, including organics (OA), nitrate $\left(\mathrm{NO}_{3}{ }^{-}\right)$, sulfate $\left(\mathrm{SO}_{4}{ }^{2-}\right)$, ammonium $\left(\mathrm{NH}_{4}{ }^{+}\right)$, and chloride $\left(\mathrm{Cl}^{-}\right)$were analyzed. Briefly, ambient air was sampled into the room at a flow rate of $5 \mathrm{~L} \mathrm{~min}^{-1}$. After being dried by a Nafion dryer (MD-700-24S, Perma

95 Pure, Inc.), the ambient aerosol was focused into a particle beam using an $\mathrm{PM}_{2.5}$ aerodynamic lens, and was sub-sampled into the SP-LToF-AMS at a flow rate of $\sim 0.1 \mathrm{~L} \mathrm{~min}^{-1}$. The particle beam was then vaporized upon impacting the heated tungsten surface $\left(\sim 600^{\circ} \mathrm{C}\right)$, and ionized by electron ionization $(70 \mathrm{eV})$ to produce positive fragments, which were detected and analyzed by the LToF mass spectrometer. The ionization efficiency (IE) as well as relative ionization efficiency (RIE) calibrations

100 were conducted during the campaign, using the $350 \mathrm{~nm}(\mathrm{Dm})$ ammonium nitrate $\left(\mathrm{NH}_{4} \mathrm{NO}_{3}\right)$ and ammonium sulfate $\left(\left(\mathrm{NH}_{4}\right)_{2} \mathrm{SO}_{4}\right)$ particles (Jimenez et al., 2003). Meanwhile, gases species including $\mathrm{CO}, \mathrm{NO}_{2}, \mathrm{O}_{3}$ and $\mathrm{SO}_{2}$ were measured using Thermo Scientific gases monitors, and the meteorological parameters including relative humidity $(\mathrm{RH})$ and temperature were measured by an automatic weather station (MAWS201, Vaisala, Vantaa, Finland).

\subsection{Data analysis}

The SQUIRREL (version 1.61D) and PIKA (1.21D) coded in Igor Pro 6.37 (WaveMetrics) were used to analyze the SP-LToF-AMS data. Standard RIEs of 1.4, 1.1 and 1.3 were used for organics, nitrate 
and chloride, respectively, while experimentally determined RIEs of 3.7 and 1.3 were used for ammonium and sulfate, respectively. Meanwhile, the composition-dependent collection efficiency (CDCE) was used to calibrate and compensate for the incomplete detection due to particle bounce (Middlebrook et al., 2012). The elemental ratios including oxygen-to-carbon (O/C), organic mass-toorganic carbon $(\mathrm{OM} / \mathrm{OC})$ and hydrogen-to-carbon $(\mathrm{H} / \mathrm{C})$ were also analyzed for the high-resolution $\mathrm{OA}$ mass spectra based on the Improved Ambient (I-A) method (Canagaratna et al., 2015). Meanwhile, the data and error matrices of high-resolution OA mass spectra for $\mathrm{m} / \mathrm{z}$ 12-120 were preprocessed, and OA source apportionment was performed using Positive Matrix Factorization (PMF) and multilinear engine (ME-2) in Igor Pro (Paatero, 1999), as conducted in Duan et al (2021).

Six OA sources were resolved, including a hydrocarbon-like OA (HOA), a cooking OA (COA), a biomass burning OA (BBOA), a coal combustion OA (CCOA), a biomass burning influencedoxygenated OA (OOA-BB), and an aqueous phase processed-oxygenated OA (aq-OOA) (Fig. S1 and Fig. 2). Both the mass spectrum of HOA and COA are characterized by prominent hydrocarbon ion series of $\mathrm{C}_{n} \mathrm{H}_{2 n-1}$ and $\mathrm{C}_{n} \mathrm{H}_{2 n+1}$, while the COA contains higher signal at $\mathrm{C}_{n} \mathrm{H}_{2 n-1}$ than $\mathrm{C}_{n} \mathrm{H}_{2 n+1}$, an especially much higher signal ratio of $\mathrm{C}_{4} \mathrm{H}_{7}{ }^{+} / \mathrm{C}_{4} \mathrm{H}_{9}{ }^{+}$which is the typical characteristic of COA profile as reported in previous studies at various urban sites (He et al., 2011; $\mathrm{Ng}$ et al., 2011a). The HOA was emitted mainly from local traffic with mass peaks in traffic hours, and COA was dominantly associated with the cooking emissions, exhibiting mass peaks at around breakfast, lunch and dinner times (Fig. S1). Meanwhile, the time series of COA correlated well with that of $\mathrm{C}_{6} \mathrm{H}_{10} \mathrm{O}^{+}(r=0.85)$, which is a tracer fragment of cooking emissions (Hu et al., 2016) (Fig. S1). The mass spectrum of CCOA is dominated by unsaturated hydrocarbons, particularly polycyclic aromatic hydrocarbons (PAH)-related ion peaks (e.g., m/z 77, 91 and 115) (Dall'Osto et al., 2013; Hu et al., 2013). In comparison, BBOA was mainly

130 emitted from the combustion of biomass fuel such as wood or straw, with the tracer signal at $\mathrm{m} / \mathrm{z} 60$ (dominantly $\mathrm{C}_{2} \mathrm{H}_{4} \mathrm{O}_{2}{ }^{+}$), which is mainly enhanced by biomass-burning tracer levoglucosan and related species (mannosan, galactosan, etc.) (Cubison et al., 2011). Consistently, a good correlation between the time series of BBOA and the $\mathrm{C}_{2} \mathrm{H}_{4} \mathrm{O}_{2}{ }^{+}$fragment was also observed ( $r=0.95$ ) (Fig. S1). Two SOAs including OOA-BB and aq-OOA both contain prominent peaks at $\mathrm{m} / \mathrm{z} 44$ (mainly $\mathrm{CO}_{2}{ }^{+}$), but the mass spectrum of OOA-BB shows a higher peak at $\mathrm{m} / \mathrm{z} 43$ (mainly $\mathrm{C}_{2} \mathrm{H}_{3} \mathrm{O}^{+}$) and a lower $\mathrm{O} / \mathrm{C}$ ratio $(0.57$ ) than that of aq-OOA (0.82). The tight correlation between the time series of $\mathrm{C}_{2} \mathrm{H}_{3} \mathrm{O}^{+}$and OOA-BB $(r=$ 0.83 ) also suggests its less oxidized property (Fig. S1). In comparison, aq-OOA has a mass spectrum with a much higher peak at $\mathrm{m} / \mathrm{z} 44$ (mainly $\mathrm{CO}_{2}{ }^{+}$) than $\mathrm{m} / \mathrm{z} 43$, and a largely different time series with OOA-BB, implying different formation processes between OOA-BB and aq-OOA which will be discussed in detail in the sections 3.2 and 3.3, respectively.

In addition, the aerosol liquid water content (ALWC) was also calculated based on the ISORROPIA-II model, using inorganic aerosol composition $\left(\mathrm{NH}_{4}{ }^{+}, \mathrm{SO}_{4}{ }^{2-}, \mathrm{NO}_{3}{ }^{-}, \mathrm{Cl}^{-}\right)$combined with ambient temperature and RH as input data (Fountoukis and Nenes, 2007). The simulation was run in "metastable" mode in which all components are assumed to be deliquescent and no solid matter is present. The thermodynamic equilibrium and phase state of those inorganic species were then simulated and the 
ALWC was resolved.

\section{Results and discussion}

\subsection{Overview of NR-PM 2.5 composition and OA sources in winter Xi'an}

During the winter of 2018 in Xi' an, NR-PM 2.5 concentration varied from $5.9 \mu \mathrm{g} \mathrm{m}^{-3}$ to $205.6 \mu \mathrm{g} \mathrm{m}^{-3}$, with an average of $68.0 \pm 42.8 \mu \mathrm{g} \mathrm{m}^{-3}$ (see Fig. 1 and Table S1). This average concentration was higher than that measured in the summer of 2019 in Xi' an $\left(22.3 \mu \mathrm{g} \mathrm{m}^{-3}\right.$, Duan et al., 2021), due to the increase of source emissions in winter than in summer which was also observed in other cities (Sun et al., 2015; $\mathrm{Xu}$ et al., 2014, 2016). Meanwhile, the average NR-PM 2.5 concentration observed in our study was

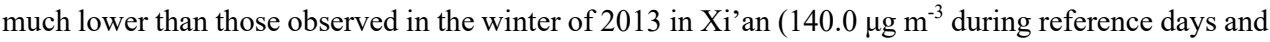
$537.0 \mu \mathrm{g} \mathrm{m}^{-3}$ during haze days, respectively) (Elser et al., 2016), pointing to an improved air quality. However, haze events with $\mathrm{NR}_{-} \mathrm{PM}_{2.5}$ concentrations higher than $100 \mu \mathrm{g} \mathrm{m}^{-3}$ were still observed frequently during the campaign, indicating some overlooked pollution sources or atmospheric formation pathways which require further attention. As for the chemical composition, OA constituted a dominant fraction of $54 \%$ in total NR-PM 2.5 mass, lower than that observed in summer $\mathrm{Xi}$ 'an $(63 \%)$. Nitrate contributed $20 \%$ to total NR-PM 2.5 mass, followed by sulfate $(13 \%)$, ammonium (10\%), and chloride $(3 \%)$. The higher contribution of nitrate than sulfate was opposite to that in summer with higher contribution from sulfate $(17 \%)$ than nitrate $(12 \%)$, suggesting the increased formation and contribution of nitrate in winter pollution, likely due to the much lower temperature in winter which promoted the transformation of nitrate from gas-phase to particle-phase (Duan et al., 2021). Meanwhile, the

165 contribution of nitrate in our campaign was also higher than that observed in Xi'an during the winter of 2013 (by 13\% during haze days and by 10\% during reference days, respectively) (Elser et al., 2016), suggesting the increasing importance of nitrate pollution over sulfate pollution in recent years, consistent with the interannual evolution trend of nitrate observed in Beijing (Xu et al, 2019).

A continuous and large increase of secondary inorganic aerosol (SIA, nitrate + sulfate + ammonium) was observed during two periods, including period 1 from 2018/12/30 to 2019/1/15 (SIA-enhanced period 1, SIA_P1) and period 2 from 2019/2/7 to 2019/3/4 (SIA-enhanced period 2, SIA_P2). The other periods are defined as reference days. During the reference days, OA contributed a major fraction of $65 \%$ to total NR-PM 2.5 mass, even higher than that during the summer of 2019 in Xi' an (63\%) (Duan et al., 2021). In comparison, from reference days to SIA_P1 and SIA_P2, the contribution of OA

175 decreased from $66 \%$ to $52 \%$ and $44 \%$, respectively, and the contribution of SIA increased from $30 \%$ to $45 \%$ and 53\%, accordingly. Meanwhile, the SIA-enhanced periods were also related to higher $\mathrm{PM}_{2.5}$ concentration, which increased from $44.1 \mu \mathrm{g} \mathrm{m}^{-3}$ during reference days to $131.0 \mu \mathrm{g} \mathrm{m}^{-3}$ during SIA_P1 and $84.9 \mu \mathrm{g} \mathrm{m}^{-3}$ during SIA_P2, suggesting the much important contribution of SIA in the formation of haze pollution in winter Xi'an. The major difference between SIA-enhanced periods and reference days

180 was the much frequent occurrence of higher relative humidity (RH>60\%) and ALWC concentration (ALWC $>10 \mu \mathrm{g} \mathrm{m}^{-3}$ ) during SIA_P1 and SIA_P2 than reference days, suggesting that high RH and liquid phase condition may drive the large production of SIA (Fig. S2) (Xu et al., 2019; Duan et al., 
2021). Specifically, the increase ratio of sulfate contribution from reference days to SIA_P1 (1.8) and to SIA_P2 (2.1) was higher than those of nitrate (1.4 for SIA_P1 and 1.5 for SIA_P2, respectively) (Fig. 1). As a result, the average mass ratio of $\mathrm{NO}_{3}{ }^{-} / \mathrm{SO}_{4}{ }^{2-}$ decreased from 1.9 during reference days to 1.5 during SIA_P1 and 1.4 during SIA_P2, respectively. $\mathrm{NO}_{3}{ }^{-} / \mathrm{SO}_{4}{ }^{2-}$ showed an evident decrease as a function of RH at higher NR-PM 2.5 loading $\left(>50 \mu \mathrm{g} \mathrm{m}^{-3}\right.$ ) (Fig. S2). Consistently, although both sulfur oxidation ratio (SOR) and nitrogen oxidation ratio (NOR) increased with $\mathrm{RH}, \mathrm{SOR}$ increased from 0.10 0.20 at $\mathrm{RH}<40 \%$ to $0.33-0.63$ at $\mathrm{RH}>60 \%$, which was more efficient than the increase of NOR (from $0.07-0.10$ at $\mathrm{RH}<40 \%$ to $0.18-0.30$ at $\mathrm{RH}>60 \%$ ) (Fig. S3). These results suggested that high $\mathrm{RH}$ is favorable in promoting sulfate formation than nitrate formation especially in haze pollution in winter Xi'an.

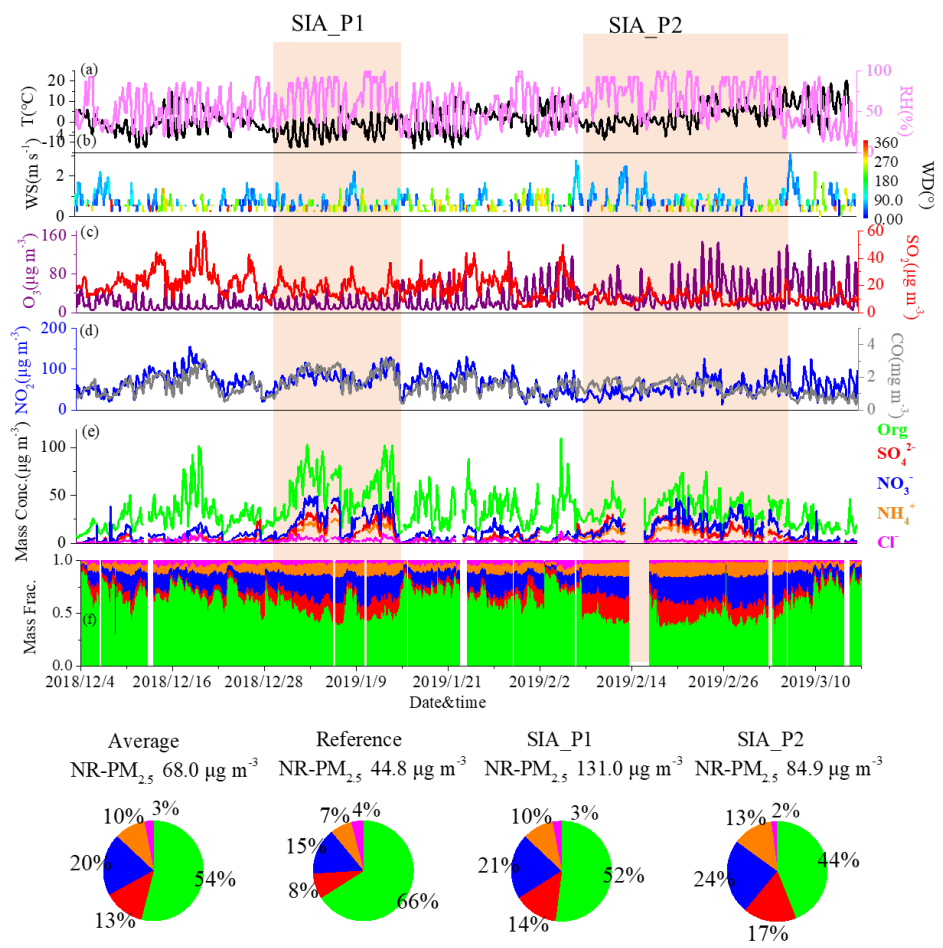

Fig. 1 Time series of meteorology parameters (relative humidity $(\mathrm{RH})$, temperature $(\mathrm{T})$, wind speed (WS), and wind direction (WD) (a, b); gases species $\left(\mathrm{SO}_{2}, \mathrm{O}_{3}, \mathrm{NO}_{2}\right.$ and $\mathrm{CO}$ ) (c, d); and NR-PM 2.5 composition $(\mathrm{e}, \mathrm{f})$ in the winter of 2018 in Xi'an. The average composition of NR-PM 2.5 for the entire winter campaign, as well as reference days and SIA-enhanced periods (SIA_P1 and SIA_P2) are also shown. 
mass. HOA contributed $8 \%$ to the total OA mass (Fig. 2). This contribution was lower than that observed in winter 2013 (by $16-18 \%$ ) (Elser et al., 2016), which may be related to the better traffic control in recent years in urban Xi'an. COA on average contributed $13 \%$ to total OA, which was higher than that observed during winter 2013 ( 4-9\%) in Xi'an (Elser, et al., 2016; Duan et al., 2021). CCOA on average contributed $9 \%$ to total OA in this winter campaign, consistent with that observed in the winter of 2013 ( 6-14\%) (Elser et al., 2016). In comparison, BBOA was more significant contributor than CCOA, and on average accounted for $12 \%$ of total OA mass. However, this contribution was much lower than that observed in the winter of 2013 in Xi'an ( 40\%) (Elser et al., 2016), suggesting the reduction of BBOA emissions in recent years in $\mathrm{Xi}$ ' an and surrounding areas. SOA contributed a higher fraction of 58\% than POA to total OA, with OOA-BB and aq-OOA accounting for $24 \%$ and $34 \%$ of OA mass, respectively. The contribution of SOA was much higher than that observed in the winter of 2013 in $\mathrm{Xi}$ an (16\% in reference days and $31 \%$ in haze days, respectively) (Elser et al., 2016), suggesting enhanced formation of SOA in recent years.
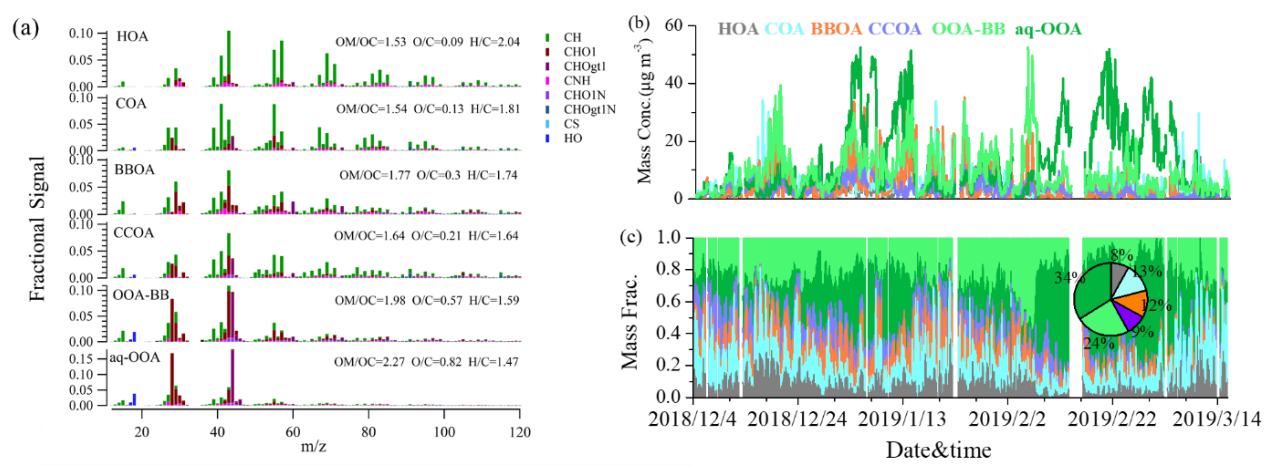

Fig. 2 Mass spectra of OA sources (a), and time series of concentration (b) and fraction (c) of each OA source in total OA mass during the winter campaign. The average composition of OA sources for the entire observation are also shown as pie chart in figure $\mathrm{c}$.

\subsection{OOA-BB dependence on BBOA and photochemical oxidation}

We further analyzed the evolution and formation mechanism of OOA-BB, and found that the time variation of OOA-BB correlated well with that of BBOA $\left(\mathrm{R}^{2}=0.59\right)($ Fig. S4), with peaks of $\mathrm{m} / \mathrm{z} 60$ $\left(\mathrm{C}_{2} \mathrm{H}_{4} \mathrm{O}_{2}{ }^{+}\right)$and $\mathrm{m} / \mathrm{z} 73\left(\mathrm{C}_{3} \mathrm{H}_{5} \mathrm{O}_{2}{ }^{+}\right)$in the mass spectrum of OOA-BB (Fig. 2), indicating the possible influence of BBOA source on the formation of OOA-BB.

The fragment ions of $\mathrm{m} / \mathrm{z} 60\left(\mathrm{C}_{2} \mathrm{H}_{4} \mathrm{O}_{2}{ }^{+}\right)$and $\mathrm{m} / \mathrm{z} 73\left(\mathrm{C}_{3} \mathrm{H}_{5} \mathrm{O}_{2}{ }^{+}\right)$generated from the pyrolysis of cellulose such as levoglucosan and mannosan were considered as good tracers of BBOA (Alfarra et al., 2007; Cubison et al., 2011). Fresh BBOA usually exhibits the highest content of $\mathrm{m} / \mathrm{z} 60\left(\mathrm{C}_{2} \mathrm{H}_{4} \mathrm{O}_{2}{ }^{+}\right)$and $\mathrm{m} / \mathrm{z}$ $73\left(\mathrm{C}_{3} \mathrm{H}_{5} \mathrm{O}_{2}^{+}\right)$, which will decrease due to oxidation reaction and degradation during atmospheric aging. At the same time, oxygenated fragments such as $\mathrm{m} / \mathrm{z} 44\left(\mathrm{CO}_{2}{ }^{+}\right)$will increase during atmospheric aging (Cubison et al., 2011; Paglione et al., 2020). The correlation and evolution of $f_{60}$ (the fraction of $\mathrm{m} / \mathrm{z} 60$ 
in the total signal of the OA mass spectrum) and $f_{44}$ (the fraction of $\mathrm{m} / \mathrm{z} 44$ in the total signal of the OA mass spectrum) is usually used to analyze the influence of BBOA on SOA and their evolution processes (Cubison et al., 2011). Fig. 3a displays plots of $f_{44}\left(f_{\mathrm{CO} 2+}\right)$ vs. $f_{60}\left(f_{\mathrm{C} 2 \mathrm{H} 4 \mathrm{O} 2+}\right)$ of BBOA and SOA sources resolved by source apportionment of OA in $\mathrm{PM}_{2.5}$ in the winter of 2018 (this campaign), the winter of 2013 (Elser et a., 2016) and the summer of 2019 (Duan et al., 2021), in order to analyze the influence of BBOA on SOA formation in Xi'an. BBOA factor resolved in the winter of 2018 and 2013 were both located in the fresh BBOA region with higher $f_{\mathrm{C} 2 \mathrm{H} 4 \mathrm{O} 2+}\left(0.024\right.$ and 0.021 , respectively) and lower $f_{\mathrm{CO} 2+}$, suggesting they were fresh BBOA emissions. OOA-BB resolved in the winter of 2018 was characterized by a $f_{\mathrm{C} 2 \mathrm{H} 4 \mathrm{O} 2+}$ value of 0.08 and a $f_{\mathrm{CO} 2+}$ value of 0.13 , which was located in the BB-influenced region, indicating the OOA-BB resolved in the winter of 2018 was largely influenced by BBOA emission. In comparison, the aq-OOA resolved in the winter of 2018, OOA resolved in the winter of 2013, as well as the three SOA sources (LO-OOA, MO-OOA, aq-OOA) resolved in the summer of 2019 all showed higher $f_{\mathrm{CO} 2+}$ and lower $f_{\mathrm{C}_{2} \mathrm{H} 4 \mathrm{O} 2+}(<0.005)$, and were located in the non-BB influenced region, suggesting that these SOA were formed from other processes independent on BBOA source. In addition, $f_{44}$ vs. $f_{60}$ for $\mathrm{BBOA}$ and SOA resolved in $\mathrm{PM}_{1}-\mathrm{OA}$ from previous studies were also compared (see Fig. 3b). In

245 most of studies, BBOA is located in the fresh BBOA region, except the BBOA resolved in the winter of 2012 in Xi'an (Zhong et al., 2020). Meanwhile, most of the SOAs were located in the non-BB influenced region, except the OOA resolved in the winter of 2012 (Zhong et al., 2020) which showed a higher $f_{44}$ of 0.17 and a higher $f_{60}$ of $0.09(>0.05)$. In comparison, the MO-OOA resolved in Baoji and the OOA resolved in Shijiazhuang also showed minor influence from BBOA, which are located in the edge of the aged-BB region (Wang et al., 2017; Huang et al., 2019).

In order to further explain the possible pathway of OOA-BB formation and influence from BBOA in the 2018 winter campaign, the evolution of BBOA into OOA-BB was further analyzed using the van Krevelen (VK) diagram of $\mathrm{O} / \mathrm{C}$ vs. $\mathrm{H} / \mathrm{C}$ ratios, which is typically used to investigate the OA evolution during field and laboratory experiments (Heald et al., 2010; $\mathrm{Ng}$ et al., 2011b). As shown in Fig. 3c, the 255 slope of the line that links BBOA to OOA-BB is -0.59 , between -0.5 and -1 , suggesting that OOA-BB was likely formed from BBOA through the formation of carboxylic acid moieties (Ng et al., 2011b; Paglione et al., 2020). Meanwhile, in our study, the concentration of OOA-BB positively increased as the Ox increased, suggesting the importance of photochemical oxidation processes (Fig. 3d). Meanwhile, the formation of OOA-BB was also enhanced under higher BBOA concentration conditions, confirming that OOA-BB was formed from the aging of BBOA. 


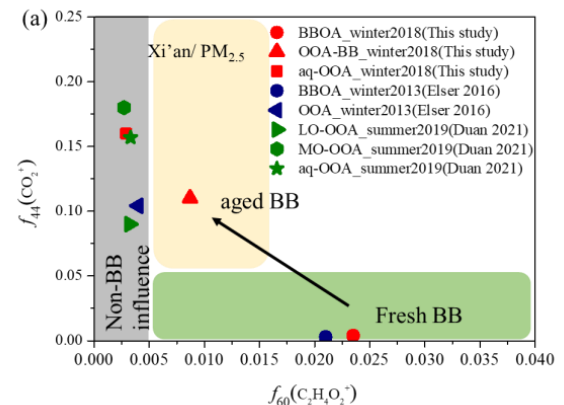

(c)

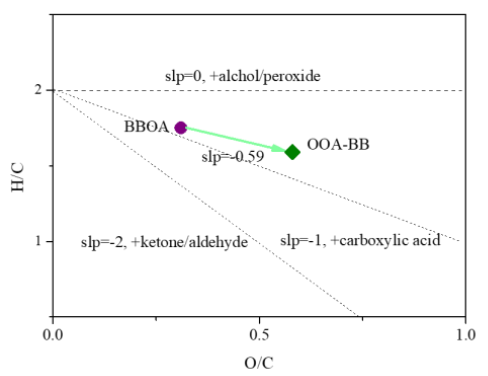

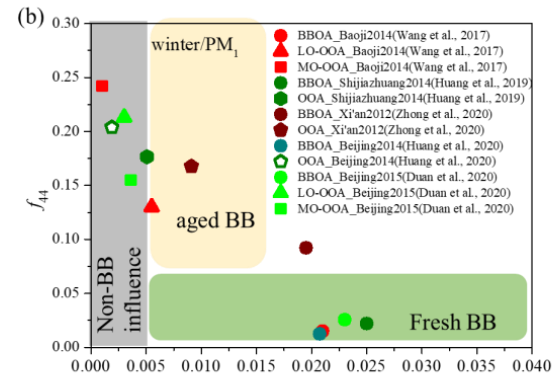

(d)

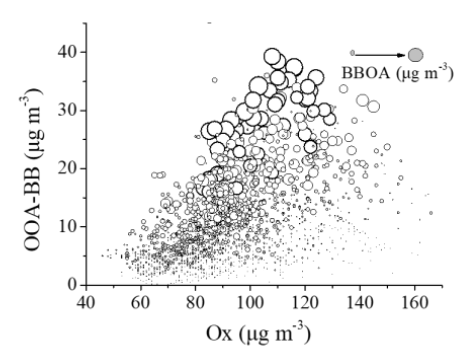

Fig. 3 Plots of $f_{44}$ vs. $f_{60}$ for BBOAs and SOAs resolved in OA of $\mathrm{PM}_{2.5}$ in Xi'an (a); plots of $f_{44}$ vs. $f_{60}$ for BBOAs and SOAs resolved in $\mathrm{OA}_{\text {of }} \mathrm{PM}_{1}$ in our previous campaigns conducted in Xi'an, Baoji, Shijiazhuang and Beijing(b); the van Krevelen (VK) diagram of the BBOA and OOA-BB factors resolved in the winter of 2018 in Xi' an (c); and the effects of Ox and BBOA concentrations on the OOA-BB formation (d).

\section{3 aq-OOA dependence on SIA and ALWC}

The aq-OOA showed an obvious mass increase during the SIA-enhanced periods, and tracked well with the ALWC increase during this winter campaign (Fig. 4). In addition, the mass spectrum of aq-OOA resolved in this study was tightly correlated with that resolved in the summer of 2019 in Xi' an (Duan et al., 2021) $\left(\mathrm{R}^{2}=0.86\right.$, Fig. S5), and the time series of aq-OOA was also correlated well with $\mathrm{CH}_{2} \mathrm{O}_{2}{ }^{+}$ $\left(\mathrm{R}^{2}=0.91\right), \mathrm{CH}_{3} \mathrm{SO}^{+}\left(\mathrm{R}^{2}=0.89\right)$, and $\mathrm{CH}_{3} \mathrm{SO}_{2}{ }^{+}\left(\mathrm{R}^{2}=0.75\right)$ (Fig. S5), which are the typical fragment ions of aqueous-phase processing products (Tan et al., 2009; Sun et al., 2016). These results suggested the dominant role of aqueous-phase processes in the formation of aq-OOA in winter Xi'an. As shown in Fig. 4b, there was a positive correlation between the concentration of aq-OOA and ALWC with variable slopes in different RH ranges, likely due to the exponential increase of ALWC with RH (Wu et al., 2018). As discussed by Wu et al. (2018), simultaneously elevated RH levels and SIA concentrations resulted in an abundant ALWC, which could further facilitate the SOA formation. Consistently, higher SIA concentration also showed positive promotion on the aq-OOA increase (Fig. 4b), and a tight correlation between the concentration of aq-OOA and SIA was observed for the whole dataset irrespective of the $\mathrm{RH}$ variation $\left(\mathrm{R}^{2}=0.96\right.$, Fig. S6). 
(a)

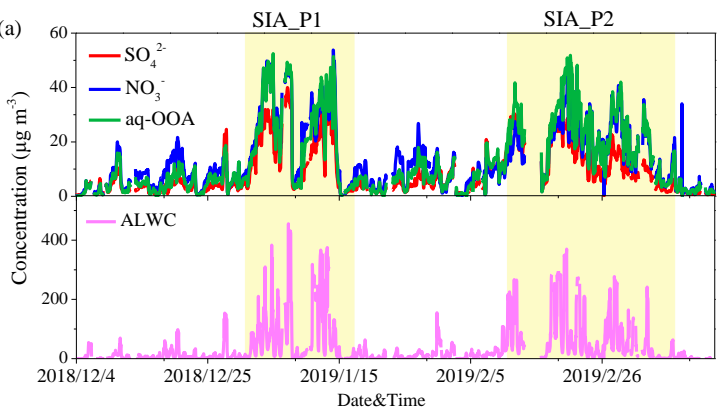

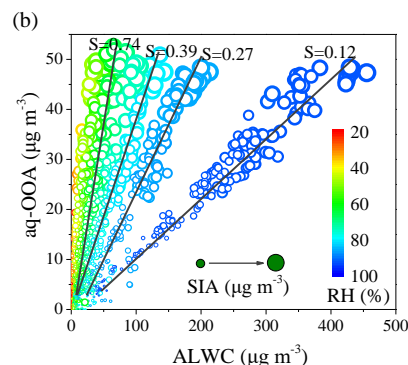

Fig. 4 Time series of aq-OOA, sulfate, nitrate, and ALWC during the winter campaign in Xi' an (a), and the effects of ALWC on the formation of aq-OOA colored by RH, with the increase of SIA concentration shown as the size increase of the data points (b).

We further compared the aqueous-phase formation of aq-OOA during summer 2019 and winter 2018 in $\mathrm{Xi}$ ' an, and discussed the specific effect of sulfate or nitrate on their formations (Fig. 5). As discussed in our previous study (Duan et al., 2021), aq-OOA was dominantly formed in fog-rain days with consistently high RH $(>60 \%)$ and ALWC conditions during summer. The concentration of aq-OOA continuously increased as $\mathrm{RH}$ increased from $70 \%$ to $100 \%$ and ALWC increased from $10 \mu \mathrm{g} \mathrm{m}^{-3}$ to $100 \mu \mathrm{g} \mathrm{m}^{-3}$ and further to $1000 \mu \mathrm{g} \mathrm{m}^{-3}$, suggesting the much important effects of high RH and ALWC on the aq-OOA formation in summer Xi'an (Fig. 5a, b). In addition, nitrate displayed a more positive promotion on the aq-OOA formation than sulfate, as sulfate showed a weak correlation $\left(\mathrm{R}^{2}=0.44\right)$ with aq-OOA than that of nitrate $\left(\mathrm{R}^{2}=0.98\right)$ (Fig. S7). Different from aq-OOA in summer that was mainly formed when $\mathrm{RH}>60 \%$, the formation of aq-OOA in winter was frequently observed when $\mathrm{RH}>40 \%$ (Fig. 5c, d). This may be related to the much higher nitrate contribution during winter which reduced the deliquesce $\mathrm{RH}$ of the aerosol mixture and provided liquid condition for aq-OOA formation at even lower RH (Xue et al., 2014; Wu et al., 2018). When the ALWC was higher than $10 \mu \mathrm{g} \mathrm{m}^{-3}$, aq-OOA was formed efficiently, and both nitrate and sulfate displayed positive promotions on aq-OOA increase. Different from summer, the concentration of aq-OOA was not continuously increasing when ALWC increased from 10-100 $\mu \mathrm{g} \mathrm{m}^{-3}$ to $>100 \mu \mathrm{g} \mathrm{m}^{-3}$. Instead, the aq-OOA concentration was much affected by the mass increase of nitrate and sulfate, with similar aq-OOA concentration associated with similar sulfate or nitrate concentration level under different RH ranges. This may suggest that aq-OOA was bulk water reaction during summer while during winter aq-OOA formation is more driven by heterogeneous surface reactions. Also as shown in Fig. 4b, the correlation slope (S) between aq-OOA and ALWC decreased from 0.74 for $\mathrm{RH}<70 \%$ to 0.12 for $\mathrm{RH}>90 \%$, which means that when the ALWC exponentially increased with high $\mathrm{RH}$, aq-OOA did not increase proportionally. These results suggest that SIA may play a much important role in the formation of aq-OOA in winter Xi'an. 

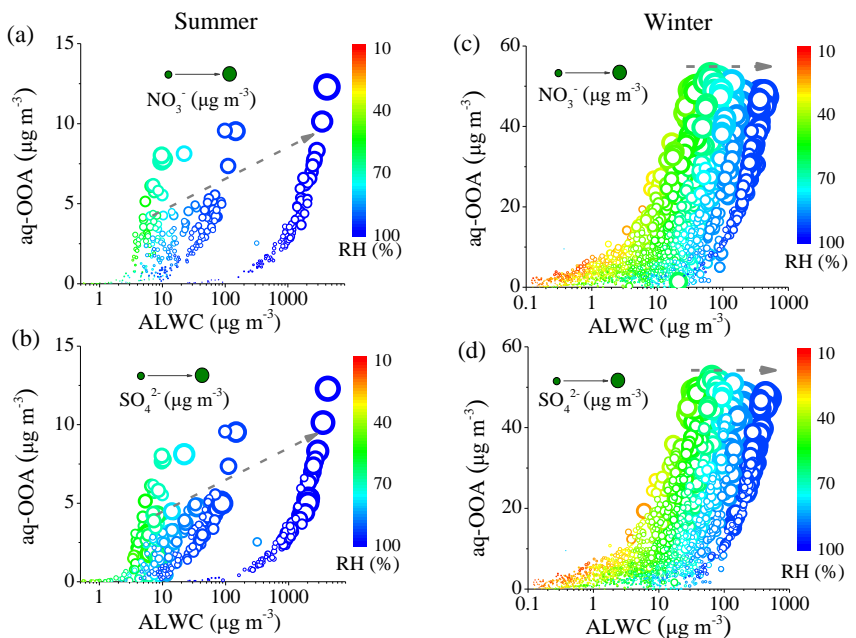

Fig. 5 Correlations between ALWC and aq-OOA colored by RH during summer (a, b) and winter (c, d) in Xi'an. The effects of nitrate and sulfate are also shown in (a, c) and (b, d), respectively, in which the increase of sulfate or nitrate concentration is shown as the size increase of the data points. The horizontal axes both in summer and winter were shown in exponential type for comparison.

\subsection{Haze pollution in winter Xi'an: enhanced contribution of aqueous-phase processes}

As discussed above, the SIA-enhanced periods were usually related to haze pollution with higher NR$\mathrm{PM}_{2.5}$ mass. OA composition between reference days and SIA-enhanced periods was further compared in Fig. 6, in order to better understand the OA evolution during haze pollution in Xi' an. From reference days to SIA_P1, the total mass of OA increased from $28.7 \mu \mathrm{g} \mathrm{m}^{-3}$ to $68.0 \mu \mathrm{g} \mathrm{m}^{-3}$ (Table S1). Both POAs and SOAs concentrations increased, with the aq-OOA increasing the most from $4.9 \mu \mathrm{g} \mathrm{m}^{-3}$ to $26.2 \mu \mathrm{g}$ $\mathrm{m}^{-3}$. As a result, the $\mathrm{O} / \mathrm{C}$ ratio of the bulk $\mathrm{OA}$ increased from 0.41 during reference days to 0.52 during

325 SIA_P1, suggesting the enhanced OA oxidation state during SIA_P1. In comparison, the total mass of OA $\left(37.7 \mu \mathrm{g} \mathrm{m}^{-3}\right)$ during SIA_P2 was higher than that during reference days, while lower than that during SIA_P1. The mass concentrations of POAs and OOA-BB were lower than those during both reference days and SIA_P1, and the increase of the total OA mass from reference days to SIA_P2 was dominantly ascribed to the dramatic increase of aq-OOA from $4.9 \mu \mathrm{g} \mathrm{m}^{-3}$ to $22.7 \mu \mathrm{g} \mathrm{m}^{-3}$, similar with that from reference days to SIA_P1. As a result, the O/C ratio of total OA during SIA_P2 was further enhanced to 0.67 , much higher than those during reference days and SIA_P1. 

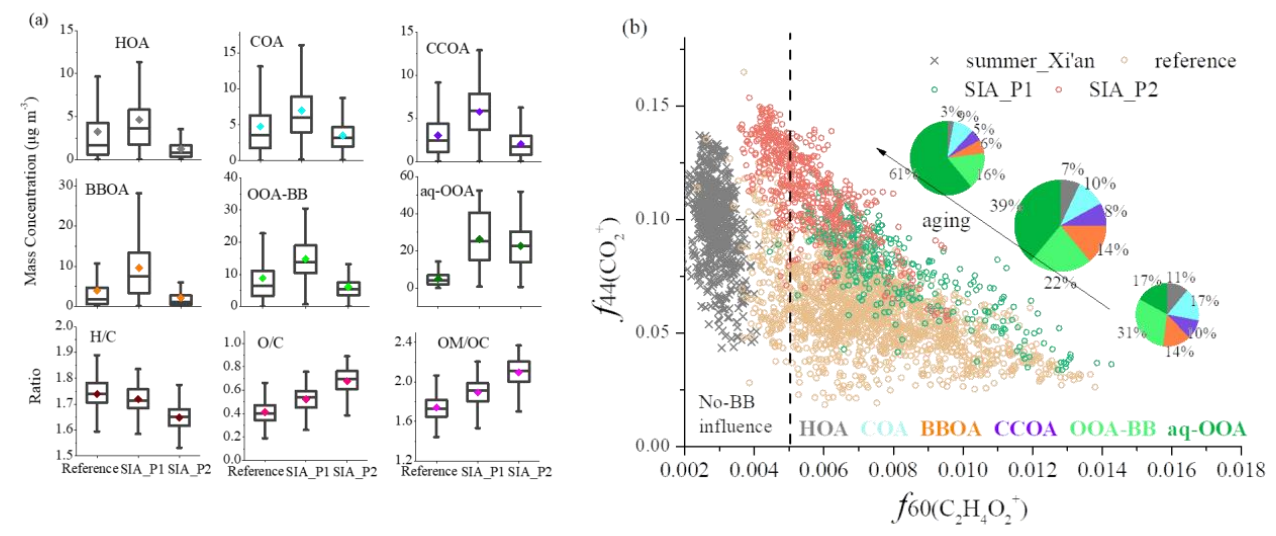

Fig. 6 Mass concentrations of OA sources, OA oxidation ratios $(\mathrm{H} / \mathrm{C}, \mathrm{O} / \mathrm{C}$ and $\mathrm{OM} / \mathrm{OC})$ during different periods including reference days, SIA_P1 and SIA_P2 (a), and the plots of $f_{44}$ vs $f_{60}$, as well as the average OA composition during these three periods (b). The size of the pie chart identifies the mass concentration of total OA, and the plots of $f_{44}$ vs $f_{60}$ in summer 2019 was also shown for comparison.

The scatterplot of $f_{44}$ vs. $f_{60}$ was also applied to further investigate OA transformation during different periods. Also as discussed above, in the $f_{44}$ vs. $f_{60}$ space, data from biomass burning appear in the lower right part, while data with negligible biomass burning influence are concentrated on the left side as a band shape (Cubison et al., 2011). As shown in Fig.6b, data during the summer of 2019 in Xi'an were mainly located on the left side $\left(f_{60}=0.1-0.5 \%\right)$, consistent with the negligible biomass burning influence and BBOA-absent OA sources in the summer campaign (Duan et al., 2021). In the winter campaign, the data were mainly located in the lower right part with $f_{60}$ ranging from $0.4 \%-1.4 \%$ during reference days, suggesting significant influence of BBOA. The data during SIA-P1 were also mainly located in the lower right part with $f_{60}$ ranging from $0.7 \%-1.4 \%$, suggesting BBOA also had significant influence during this period. Meanwhile, more data were located in the upper range with higher $f_{44}$ than those in reference days, suggesting the increased OA aging and secondary formation during SIA_P1. As for SIA_P2, more data were located on the left side with no-BB influence, and the range of $f_{44}$ was further higher than those in reference days and SIA_P1, suggesting that the BBOA influence decreased while the SOA influence and OA oxidation state increased during the SIA_P2. Consistently, from reference days and SIA_P1 to SIA_P2, the contribution of BBOA decreased from $13 \%$ and $14 \%$ to $6 \%$, and the OOA-BB contribution decreased from $31 \%$ and $22 \%$ to $16 \%$, respectively, and the aq-OOA contribution increased largely from $19 \%$ and $39 \%$ to $61 \%$.

355 The VK diagram, displaying the variation of O/C vs H/C (Hu et al., 2013), was further used to probe OA oxidation reaction mechanisms in our study. As shown in Fig. 7a, data with a higher $\mathrm{O} / \mathrm{C}$ ratio and lower $\mathrm{H} / \mathrm{C}$ ratio located in the right-bottom corner were usually related to higher SIA concentration, and higher ALWC also promoted the increase of $\mathrm{O} / \mathrm{C}$ ratio, suggesting the promotion of SIA and aqueous- 
phase processes on the OA oxidation enhancement during winter Xi'an. The slope and intercept of the VK diagram for OA during different periods were further displayed in Fig. 7b. More data were located in the right-bottom corner with a higher $\mathrm{O} / \mathrm{C}$ ratio during SIA-enhanced periods than those during reference days, especially in SIA_P2 with a much higher fraction of aq-OOA. Meanwhile, the slope of the correlation between $\mathrm{H} / \mathrm{C}$ and $\mathrm{O} / \mathrm{C}$ during SIA-enhanced periods was also shallower than that during reference days, which changed from -0.49 during reference days to -0.39 during SIA_P1 and -0.33 during SIA_P2. This variation might suggest the transformation of OA from reference days to SIAenhanced periods, which is likely transferring much close to the processes of addition of alcohol or peroxide groups (slope $\approx 0$ ) (Heald et al., 2010; Chen et al., 2015).
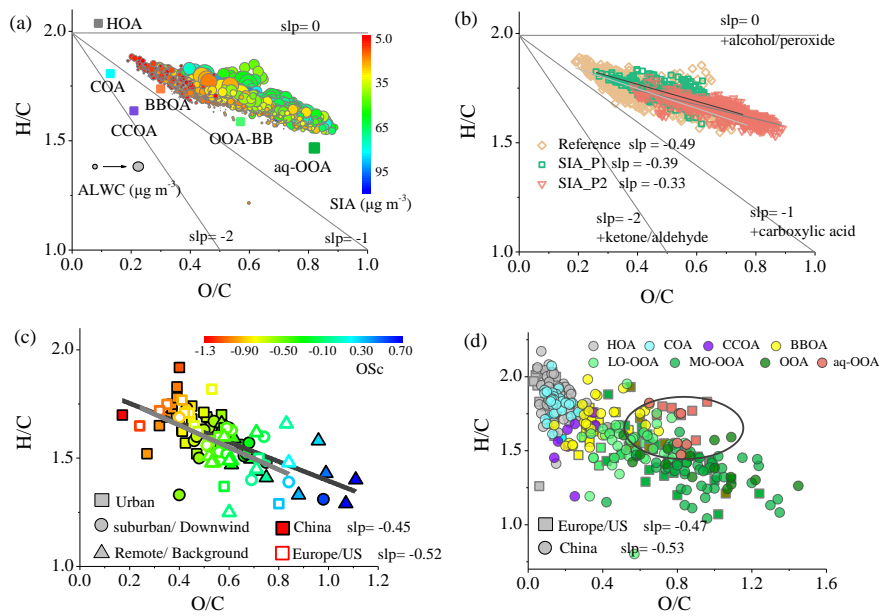

Fig. 7 The VK diagram of $\mathrm{H} / \mathrm{C}$ vs O/C for the entire winter observation (a) as well as different periods including reference days, SIA_P1 and SIA_P2 (b). The scatterplots of H/C vs O/C are colored by the mass concentration of SIA, and the size of the data points is proportional to the ALWC concentration in figure a. The scatterplots of $\mathrm{H} / \mathrm{C}$ vs $\mathrm{O} / \mathrm{C}$ of the bulk OA (c) as well as different OA factors (d) observed and resolved in urban, rural and remote sites in recent years both in China and Europe or US based on HR-AMS are also summarized for comparison.

We also explored the oxidation state of bulk OA observed in recent years in China, and compared to those observed in European or American campaigns (Fig. 7c and Table S2). Campaign-averaged O/C ratios of total $\mathrm{OA}$ observed in China range from 0.17 to 1.11 with the carbon oxidation states (OSc) ranging from -1.36 to 0.85 , which are much variable than those observed in European or American campaigns with the average $\mathrm{O} / \mathrm{C}$ ratio ranging from 0.24 to 0.84 and $\mathrm{OSc}$ ranging from -1.17 to 0.31 , respectively. As for different campaigns in China, the $\mathrm{O} / \mathrm{C}$ ratio of bulk $\mathrm{OA}$ increases from an average of 0.45 in urban sites to 0.58 in suburban or rural sites and further to 0.80 in remote or background sites, likely due to the OA aging and less influence from POA emission in rural or background sites. Meanwhile, the slope of $\mathrm{H} / \mathrm{C}$ vs. $\mathrm{O} / \mathrm{C}$ for bulk OA observed in China is -0.45 , slightly flatter than that 
observed in European or American campaigns (-0.52), while both are close to -0.5. This suggests that the carboxylic acid with fragmentation dominates OA aging from urban to remote sites both in China and European or American sites. Similarly, the VK diagram between O/C and H/C ratios for PMFresolved OA factors from AMS measurements in China is also summarized and compared to those in European or American sites (Fig. 7d). Although O/C ratios of bulk OA between China and Europe display different variation ranges, $\mathrm{O} / \mathrm{C}$ and $\mathrm{H} / \mathrm{C}$ ratios of specific $\mathrm{OA}$ factors show similar range between China and Europe or the US. Similar slope for OA factors evolution from POA to SOA is observed between China and Europe or US, which indicates the consistent characteristic of individual OA factors resolved using PMF. MO-OOA shows the highest $\mathrm{O} / \mathrm{C}$ ratio, with a range of 0.58-1.35 in China and 0.63-1.49 in Europe or US, respectively. In comparison, aq-OOA is mainly located in the range with both high $\mathrm{O} / \mathrm{C}$ ratio (0.7-1.0) and high $\mathrm{H} / \mathrm{C}$ ratio $(\geq 1.45)$, which may result in a much shallower slope for the evolution from POA to SOA (Heald et al., 2010; Chen et al., 2015). This was also consistent with the slope changes from reference days to SIA-enhanced periods for bulk OA observed in our study, as the aq-OOA enhanced obviously during the SIA-enhanced periods.

\section{Conclusion}

400 The NR-PM 2.5 chemical composition and OA sources were characterized during the heating season of 2018 in Xi'an. The average mass concentration of $\mathrm{NR}-\mathrm{PM}_{2.5}$ was $68.0 \pm 42.8 \mu \mathrm{g} \mathrm{m}^{-3}$, higher than that during the summer of 2019 but much lower than that during the winter of 2013 in Xi' an. Six OA sources including HOA, COA, CCOA, BBOA, OOA-BB, and aq-OOA were resolved, in which SOA contributed a much larger extent (58\%) than POA (42\%) to total OA mass. Further formation mechanism analysis showed that OOA-BB was mainly formed from the photochemical oxidation and aging of BBOA, which formation was more favorable in the reference days with higher BBOA concentration. In comparison, aq-OOA was dominated by the aqueous-phase processes, which showed an obvious mass increase during the SIA-enhanced periods, and tracked well with the ALWC. From reference days to SIA-enhanced periods which usually related to haze pollution, aq-OOA increased

410 obviously, with the concentration and fraction increasing from $4.9 \mu \mathrm{g} \mathrm{m}^{-3}$ (17\%) during reference days to $26.2 \mu \mathrm{g} \mathrm{m}^{-3}$ (39\%) during SIA_P1 and $22.7 \mu \mathrm{g} \mathrm{m}^{-3}$ (61\%) during SIA_P2, respectively, suggesting the critical role of aqueous-phase processes in haze pollution during winter in Xi'an. Consistently, the $\mathrm{O} / \mathrm{C}$ ratio of the bulk $\mathrm{OA}$ increased from 0.41 during reference days to 0.52 during SIA_P1 and 0.67 during SIA_P2, with the VK slope of $\mathrm{H} / \mathrm{C}$ vs O/C changing from -0.49 to -0.39 and -0.33 , respectively.

415 This suggests the increased aq-OOA contribution during SIA-enhanced periods is likely transferring the OA evolution close to the processes of addition of alcohol or peroxide groups. The comparison of oxidation state of bulk OA or OA factors observed in recent years further indicates that carboxylic acid with fragmentation dominates OA aging from urban to remote sites both in China and European or American sites. Meanwhile, aq-OOA mainly located in the range with both high $\mathrm{O} / \mathrm{C}$ ratio and high

$420 \mathrm{H} / \mathrm{C}$ ratio might also result in a much shallower slope close to the alcohol or peroxide addition in the OA oxidation processes from POA to SOA. 
Data availability. Raw data used in this study are archived at the East Asian Paleoenvironmental Science Database, National Earth System Science Data Center, National Science \& Technology Infrastructure of China (http://paleodata.ieecas.cn/index.aspx).

Supplement. The Supplement related to this article is available online at

Author contributions. RJH designed the study. Data analysis and source apportionment were done by JD and RJH. JD and RJH wrote the manuscript. JD and RJH interpreted data and prepared display items. All authors commented on and discussed the manuscript.

Competing interests. The authors declare that they have no conflict of interest.

Acknowledgements. This work was supported by the National Natural Science Foundation of China (NSFC) under grant no. 41925015, the Strategic Priority Research Program of Chinese Academy of Sciences (No. XDB40000000), the Chinese Academy of Sciences (no. ZDBS-LY-DQC001), and the Cross Innovative Team fund from the State Key Laboratory of Loess and Quaternary Geology (SKLLQG) (no. SKLLQGTD1801).

\section{Reference}

Alfarra, M. R., Prevot, A. S. H., Szidat, S., Sandradewi, J., Weimer, S., Lanz, V. A., Schreiber, D., Mohr, M., and Baltensperger, U.: Identification of the mass spectral signature of organic aerosols from wood burning emissions, Environ. Sci. Technol., 41, 5770-5777, https://doi.org/10.1021/es062289b, 2007.

An, Z. S., Huang, R.-J., Zhang, R. Y., Tie, X. X., Li, G. H., Cao, J. J., Zhou, W. J., Shi, Z. G., Han, Y. M., Gu, Z. L., and Ji, Y. M.: Severe haze in northern China: A synergy of anthropogenic emissions and atmospheric processes, Proc. Natl. Acad. Sci., 116, 8657-8666, https://doi.org/10.1073/pnas.1900125116, 2019.

Canagaratna, M. R., Jimenez, J. L., Kroll, J. H., Chen, Q., Kessler, S. H., Massoli, P., Hildebrandt Ruiz, L., Fortner, E., Williams, L. R., Wilson, K. R., Surratt, J. D., Donahue, N. M., Jayne, J. T., and Worsnop, D.R.: Elemental ratio measurements of organic compounds using aerosol mass spectrometry: characterization, improved calibration, and implications, Atmos. Chem. Phys., 15, 253-272, https://doi.org/10.5194/acp-15-253-2015, 2015.

Canonaco, F., Crippa, M., Slowik, J. G., Baltensperger, U., and Prévôt, A. S. H.: SoFi, an IGOR-based interface for the efficient use of the generalized multilinear engine (ME-2) for the source apportionment: ME-2 application to aerosol mass spectrometer data, Atmos. Meas. Tech., 6(12), 3649, https://doi.org/10.5194/amt-6-3649-2013, 2013.

Chen, Q., Heald, C. L., Jimenez, J. L., Canagaratna, M. R., Zhang, Q., He, L.-Y., Huang, X.-F., Campuzano-Jost, P., Palm, B. B., Poulain, L., Kuwata, M., Martin, S. T., Abbatt, J. P. D., Lee, A. K. Y., and Liggio, J.: Elemental Composition of Organic Aerosol: The Gap Between Ambient and 
Laboratory Measurements, Geophys. Res. Lett., 42, 4182-4189, https://doi.org/10.1002/2015GL063693, 2015.

Cubison, M. J., Ortega, A. M., Hayes, P. L., Farmer, D. K., Day, D., Lechner, M. J., Brune, W. H., Apel, E., Diskin, G. S., Fisher, J. A., Fuelberg, H. E., Hecobian, A., Knapp, D. J., Mikoviny, T., Riemer, D., Sachse, G. W., Sessions, W., Weber, R. J., Weinheimer, A. J., Wisthaler, A., and Jimenez, J. L.: Effects of aging on organic aerosol from open biomass burning smoke in aircraft and laboratory studies, Atmos. Chem. Phys., 11, 12049-12064, https://doi.org/10.5194/acp-11-12049-2011, 2011.

Dall'Osto, M., Ovadnevaite, J., Ceburnis, D., Martin, D., Healy, R. M., O’Connor, I. P., Kourtchev, I., Sodeau, J. R., Wenger, J. C., and O’Dowd, C.: Characterization of urban aerosol in Cork city (Ireland) using aerosol mass spectrometry, Atmos. Chem. Phys., 13, 4997-5015, https://doi.org/10.5194/acp-13-4997-2013, 2013.

DeCarlo, P. F., Kimmel, J. R., Trimborn, A., Northway, M. J., Jayne, J. T., Aiken, A. C., Gonin, M., Fuhrer, K., Horvath, T., Docherty, K. S., Worsnop, D. R., and Jimenez, J. L.: Field-deployable, high-resolution, time-of-flight aerosol mass spectrometer, Anal. Chem., 78, 8281-8289, https://doi.org/10.1021/ac061249n, 2006.

Duan, J., Huang, R. J., Gu, Y., Lin, C., Zhong, H., Wang, Y., Yuan, W., Ni, H.Y., Yang, L., Chen, Y., Worsnop, D.R., and O'Dowd, C.: The formation and evolution of secondary organic aerosol during summer in Xi'an: Aqueous phase processing in fog-rain days, Sci. Total. Environ., 756, 144077, https://doi.org/10.1016/j.scitotenv.2020.144077, 2021.

Elser, M., Huang, R.-J., Wolf, R., Slowik, J. G., Wang, Q., Canonaco, F., Li, G., Bozzetti, C., Daellenbach, K. R., Huang, Y., Zhang, R., Li, Z., Cao, J., Baltensperger, U., ElHaddad, I., and Prevot, A. S. H.: New insights into PM2.5 chemical composition and sources in two major cities in China during extreme haze events using aerosol mass spectrometry, Atmos. Chem. Phys., 16, 3207-3225, https://doi.org/10.5194/acp-16-3207-2016, 2016.

Fountoukis, C. and Nenes, A.: ISORROPIA II: a computationally efficient thermodynamic equilibrium model for $\mathrm{K}^{+}-\mathrm{Ca}^{2+}-\mathrm{Mg}^{2+}-\mathrm{NH}_{4}{ }^{+}-\mathrm{Na}^{+}-\mathrm{SO}_{4}{ }^{2-}-\mathrm{NO}_{3}{ }^{-}-\mathrm{Cl}^{-}-\mathrm{H}_{2} \mathrm{O}$ aerosols, Atmos. Chem. Phys., 7, 4639-4659, 2007.

Guo, S., Hu, M., Zamora, M. L., Peng, J., Shang, D., Zheng, J., Du, Z., Wu, Z., Shao, M., Zeng, L., Molina, M. J., and Zhang, R.: Elucidating severe urban haze formation in China, Proc. Natl. Acad. Sci., 111 (49), 17373-17378, https://doi.org/10.1073/pnas.1419604111, 2014.

He, L.-Y., Huang, X.-F., Xue, L., Hu, M., Lin, Y., Zheng, J., Zhang, R., and Zhang, Y.-H.: Submicron aerosol analysis and organic source apportionment in an urban atmosphere in Pearl River Delta of China using high-resolution aerosol mass spectrometry, J. Geophys. Res.-Atmos., 116, D12304, https://doi.org/10.1029/2010JD014566, 2011.

Heald, C. L., Kroll, J. H., Jimenez, J. L., Docherty, K. S., DeCarlo, P. F., Aiken, A. C., Chen, Q., Martin, S. T., Farmer, D. K., and Artaxo, P.: A simplified description of the evolution of organic aerosol composition in the atmosphere, Geophys. Res. Lett., 37, L08803, https://doi.org/10.1029/2010GL042737, 2010. 
Hu, W. W., Hu, M., Yuan, B., Jimenez, J. L., Tang, Q., Peng, J. F., Hu, W., Shao, M., Wang, M., Zeng,

L. M., Wu, Y. S., Gong, Z. H., Huang, X. F., and He, L. Y.: Insights on organic aerosol aging and the influence of coal combustion at a regional receptor site of central eastern China, Atmos. Chem. Phys., 13, 10095-10112, https://doi.org/10.5194/acp-13-10095-2013, 2013.

Hu, W. W., Hu, M., Hu, W., Jimenez, J. L., Yuan, B., Chen, W., Wang, M., Wu, Y., Chen, C., Wang, Z., Peng, J., Zeng, L., and Shao, M.: Chemical composition, sources, and aging process of submicron aerosols in Beijing: Contrast between summer and winter, J. Geophys. Res.-Atmos., 121, 19551977, https://doi.org/10.1002/2015JD024020, 2016.

Huang, R.-J., Zhang, Y. L., Bozzetti, C., Ho, K.-F., Cao, J. J., Han, Y. M., Daellenbach, K. R., Slowik, J. G., Platt, S. M., Canonaco, F., Zotter, P., Wolf, R., Pieber, S. M., Bruns, E. A., Crippa, M., Ciarelli, G., Piazzalunga, A., Schwikowski, M., Abbaszade, G., Schnelle-Kreis, J., Zimmermann, R., An, Z., Szidat, S., Baltensperger, U., Haddad, I. E., and Prévôt, A. S. H.: High secondary aerosol contribution to particulate pollution during haze events in China, Nature, 514, 218-222, https://doi.org/10.1038/nature13774, 2014.

Huang, R.-J., Wang, Y., Cao, J., Lin, C., Duan, J., Chen, Q., Li, Y., Gu, Y., Yan, J., Xu, W., Fröhlich, R., Canonaco, F., Bozzetti, C., Ovadnevaite, J., Ceburnis, D., Canagaratna, M. R., Jayne, J., Worsnop, D. R., El-Haddad, I., Prévôt, A. S. H., and O’Dowd, C. D.: Primary emissions versus secondary formation of fine particulate matter in the most polluted city (Shijiazhuang) in North China, Atmos. Chem. Phys., 19, 2283-2298, https://doi.org/10.5194/acp-19-2283-2019, 2019.

Huang, R.-J., He, Y., Duan, J., Li, Y., Chen, Q., Zheng, Y., Chen, Y., Hu, W., Lin, C., Ni, H., Dai, W., Cao, J., Wu, Y., Zhang, R., Xu, W., Ovadnevaite, J., Ceburnis, D., Hoffmann, T., and O'Dowd, C. D.: Contrasting sources and processes of particulate species in haze days with low and high relative humidity in wintertime Beijing, Atmos. Chem. Phys., 20, 9101-9114, https://doi.org/10.5194/acp20-9101-2020, 2020.

Jimenez, J. L., Jayne, J. T., Shi, Q., Kolb, C. E., Worsnop, D. R., Yourshaw, I., Seinfeld, J. H., Flagan, R. C., Zhang, X., Smith, K. A., Morris, J. W., and Davidovits, P.: Ambient aerosol sampling with an Aerosol Mass Spectrometer, J. Geophys. Res.-Atmos., 108, 8425, https://doi.org/10.1029/2001JD001213, 2003.

Jimenez, J. L., Canagaratna, M. R., Donahue, N. M., Prevot, A. S. H., Zhang, Q., Kroll, J. H., DeCarlo, P. F., Allan, J. D., Coe, H., Ng, N. L., Aiken, A. C., Docherty, K. S., Ulbrich, I. M., Grieshop, A. P., Robinson, A. L., Duplissy, J., Smith, J. D., Wilson, K. R., Lanz, V. A., Hueglin, C., Sun, Y. L., Tian, J., Laaksonen, A., Raatikainen, T., Rautiainen, J., Vaattovaara, P., Ehn, M., Kulmala, M., Tomlinson, J. M., Collins, D. R., Cubison, M. J., Dunlea, J., Huffman, J. A., Onasch, T. B., Alfarra, M. R., Williams, P. I., Bower, K., Kondo, Y., Schneider, J., Drewnick, F., Borrmann, S., Weimer, S., Demerjian, K., Salcedo, D., Cottrell, L., Griffin, R., Takami, A., Miyoshi, T., Hatakeyama, S., Shimono, A., Sun, J. Y., Zhang, Y. M., Dzepina, K., Kimmel, J. R., Sueper, D., Jayne, J. T., Herndon, S. C., Trimborn, A. M., Williams, L. R., Wood, E. C., Middlebrook, A. M., Kolb, C. E., Baltensperger, U., and Worsnop, D. R.: Evolution of Organic Aerosols in the Atmosphere, Science, 
326(5959), 1525-1529, https://doi.org/10.1126/science.1180353, 2009.

Kuang, Y., He, Y., Xu, W. Y., Yuan, B., Zhang, G., Ma, Z. Q., Wu, C. H., Wang, C. M., Wang, S. H., Zhang, S. Y., Tao, J. C., Ma, N., Su, H., Cheng, Y. F., Shao, M., and Sun, Y. L.: Photochemical aqueous-phase reactions induce rapid daytime formation of oxygenated organic aerosol on the North China Plain, Environ. Sci. Technol., 54(7), 3849-3860, https://doi.org/10.1021/acs.est.9b06836, 2020.

Lelieveld, J., Evans, J. S., Fnais, M., Giannadaki, D., and Pozzer, A.: The contribution of outdoor air pollution sources to premature mortality on a global scale, Nature, 525, 367-371, https://doi.org/10.1038/nature15371, 2015.

Li, Y. J., Sun, Y., Zhang, Q., Li, X., Li, M., Zhou, Z., and Chan, C. K.: Real-time chemical characterization of atmospheric particulate matter in China: a review, Atmos. Environ., 158, 270 304, https://doi.org/10.1016/j.atmosenv.2017.02.027, 2017.

Liu, Z., Wang, Y., Gu, D., Zhao, C., Huey, L. G., Stickel, R., Liao, J., Shao, M., Zhu, T., Zeng, L., Liu, S.-C., Chang, C.-C., Amoroso, A., and Costabile, F.: Evidence of reactive aromatics as a major source of peroxy acetyl nitrate over China, Environ. Sci. Technol., 44 (18), 7017-7022, https://doi.org/10.1021/es1007966, 2010.

Middlebrook, A. M., Bahreini, R., Jimenez, J. L., and Canagaratna, M. R.: Evaluation of compositiondependent collection efficiencies for the Aerodyne Aerosol Mass Spectrometer using field data, Aerosol Sci. Tech., 46, 258-271, https://doi.org/10.1080/02786826.2011.620041, 2012.

Ng, N. L., Canagaratna, M. R., Jimenez, J. L., Chhabra, P. S., Seinfeld, J. H., and Worsnop, D. R.: Changes in organic aerosol composition with aging inferred from aerosol mass spectra, Atmos. Chem. Phys., 11, 6465-6474, https://doi.org/10.5194/acp-11-6465-2011, 2011a.

Ng, N. L., Canagaratna, M. R., Jimenez, J. L., Zhang, Q., Ulbrich, I. M., and Worsnop, D. R.: Real-time methods for estimating organic component mass concentrations from aerosol mass spectrometer data, Environ. Sci. Technol., 45, 910-916, https://doi.org/10.1021/es102951k, $2011 \mathrm{~b}$.

Onasch, T. B., Trimborn, A., Fortner, E. C., Jayne, J. T., Kok, G. L., Williams, L. R., Davidovits, P., and Worsnop, D. R.: Soot particle aerosol mass spectrometer: development, validation, and initial application, Aerosol. Sci. Tech., 46(7), 804-817, https://doi.org/10.1080/02786826.2012.663948, 2012.

Paatero, P.: The multilinear engine: a table-driven, least squares program for solving multilinear problems, including the n-way parallel factor analysis model, J. Comput. Graph. Stat., 8, 854-888, https://doi.org/10.1080/10618600.1999.10474853, 1999.

Paglione, M., Gilardoni, S., Rinaldi, M., Decesari, S., Zanca, N., Sandrini, S., Giulianelli, L., Bacco, D., Ferrari, S., Poluzzi, V., Scotto, F., Trentini, A., Poulain, L., Herrmann, H., Wiedensohler, A., Canonaco, F., Prévôt, A. S. H., Massoli, P., Carbone, C., Facchini, M. C., and Fuzzi, S.: The impact of biomass burning and aqueous-phase processing on air quality: a multi-year source apportionment study in the Po Valley, Italy, Atmos. Chem. Phys., 20, 1233-1254, https://doi.org/10.5194/acp-20-1233-2020, 2020. 
Peng, J., Hu, M., Guo, S., Du, Z., Zheng, J., Shang, D., Levy Zamora, M., Zeng, L., Shao, M., Wu, Y., Zheng, J., Wang, Y., Glen, C. R., Collins, D. R., Molina, M. J., and Zhang, R.: Markedly enhanced absorption and direct radiative forcing of black carbon under polluted urban environments, Proc. Natl. Acad. Sci., 113 (16), 4266-4271, https://doi.org/10.1073/pnas.1602310113, 2016.

Shrivastava, M., Cappa, C. D., Fan, J. W., Goldstein, A. H., Guenther, A. B., Jimenez, J. L., Kuang, C., Laskin, A., Martin, S. T., Ng, N. L., Petaja, T., Pierce, J. R., Rasch, P. J., Roldin, P., Seinfeld, J. H., Shilling, J., Smith, J. N., Thornton, J. A., Volkamer, R., Wang, J., Worsnop, D. R., Zaveri, R. A., Zelenyuk, A., and Zhang, Q.: Recent advances in understanding secondary organic aerosol: Implications for global climate forcing, Rev. Geophys., 55, 509-559, https://doi.org/10.1002/2016RG000540, 2017.

Sun, Y. L., Wang, Z. F., Fu, P. Q., Yang, T., Jiang, Q., Dong, H. B., Li, J., and Jia, J. J.: Aerosol composition, sources and processes during wintertime in Beijing, China, Atmos. Chem. Phys., 13, 4577-4592, https://doi.org/10.5194/acp-13-4577-2013, 2013.

Sun, Y. L., Jiang, Q., Wang, Z., Fu, P., Li, J., Yang, T., and Yin, Y.: Investigation of the sources and evolution processes of severe haze pollution in Beijing in January 2013, J. Geophys. Res. Atmos., 119, 4380-4398, https://doi.org/10.1002/2014JD021641, 2014.

Sun, Y. L., Wang, Z. F., Du, W., Zhang, Q., Wang, Q. Q., Fu, P. Q., Pan, X. L., Li, J., Jayne, J., and Worsnop, D. R.: Long term real-time measurements of aerosol particle composition in Beijing, China: seasonal variations, meteorological effects, and source analysis, Atmos. Chem. Phys., 15, 10149-10165, https://doi.org/10.5194/acp-15-10149-2015, 2015.

Sun, Y. L., Du, W., Fu, P., Wang, Q., Li, J., Ge, X., Zhang, Q., Zhu, C., Ren, L., Xu, W., Zhao, J., Han, T., Worsnop, D. R., and Wang, Z.: Primary and secondary aerosols in Beijing in winter: sources, variations and processes, Atmos. Chem. Phys., 16, 8309-8329, https://doi.org/10.5194/acp-168309-2016, 2016.

Sun, Y. L., Xu, W., Zhang, Q., Jiang, Q., Canonaco, F., Prévôt, A. S. H., Fu, P., Li, J., Jayne, J., Worsnop, D. R., and Wang, Z.: Source apportionment of organic aerosol from 2-year highly time-resolved measurements by an aerosol chemical speciation monitor in Beijing, China, Atmos. Chem. Phys., 18, 8469-8489, https://doi.org/10.5194/acp-18-8469-2018, 2018.

Tan, Y., Perri, M. J., Seitzinger, S. P., and Turpin, B. J.: Effects of Precursor Concentration and Acidic Sulfate in Aqueous Glyoxal-OH Radical Oxidation and Implications for Secondary Organic Aerosol, Environ. Sci. Technol., 43, 8105-8112, https://doi.org/10.1021/es901742f, 2009.

Tong, Z., Yang, B., Hopke, P. K., and Zhang, K. M.: Microenvironmental air quality impact of a commercial-scale biomass heating system, Environ. Pollut., 220, 1112-1120, https://doi.org/10.1016/j.envpol.2016.11.025, 2017.

Wang, Y. C., Huang, R.-J., Ni, H. Y., Chen, Y., Wang, Q. Y., Li, G. H., Tie, X. X., Shen, Z. X., Huang, Y., Liu, S. X., Dong, W. M., Xue, P., Fröhlich, R., Canonaco, F., Elser, M., Daellenbach, K. R., Bozzetti, C., Haddad, E. I., and Cao, J. J.: Chemical composition, sources and secondary processes of aerosols in Baoji city of northwest China, Atmos. Environ., 158, 128-137, 
https://doi.org/10.1016/j.atmosenv.2017.03.026, 2017.

Wu, Z., Wang, Y., Tan, T., Zhu, Y., Li, M., Shang, D., Wang, H., Lu, K., Guo, S., Zeng, L., and Zhang, Y.: Aerosol liquid water driven by anthropogenic inorganic salts: implying its key role in haze formation over the North China Plain, Environ. Sci. Tech. Let., 5, 160-166, https://doi.org/10.1021/acs.estlett.8b00021, 2018.

Xu, J., Zhang, Q., Chen, M., Ge, X., Ren, J., and Qin, D.: Chemical composition, sources, and processes of urban aerosols during summertime in northwest China: insights from high-resolution aerosol mass spectrometry, Atmos. Chem. Phys., 14, 12593-12611, https://doi.org/10.5194/acp-14-125932014, 2014.

Xu, J., Shi, J., Zhang, Q., Ge, X., Canonaco, F., Prévôt, A. S. H., Vonwiller, M., Szidat, S., Ge, J., Ma, J., An, Y., Kang, S., and Qin, D.: Wintertime organic and inorganic aerosols in Lanzhou, China: sources, processes, and comparison with the results during summer, Atmos. Chem. Phys., 16, 14937-14957, https://doi.org/10.5194/acp-16-14937-2016, 2016.

Xu, W. Q., Han, T. T., Du, W., Wang, Q. Q., Chen, C., Zhao, J., Zhang, Y. J., Li, J., Fu, P. Q., Wang, Z. F., Worsnop, D. R., and Sun, Y. L.: Effects of Aqueous-Phase and Photochemical Processing on Secondary Organic Aerosol Formation and Evolution in Beijing, China, Environ. Sci. Technol., 51, 762-770, https://doi.org/10.1021/acs.est.6b04498, 2017.

Xu, W., Sun, Y., Wang, Q., Zhao, J., Wang, J., Ge, X., Xie, C., Zhou, W., Du, W., Li, J., Fu, P., Wang, Z., Worsnop, D. R., and Coe, H.: Changes in aerosol chemistry from 2014 to 2016 in winter in Beijing: Insights from high-resolution aerosol mass spectrometry, J. Geophys. Res.-Atmos., 124, 1132-1147, https://doi.org/10.1029/2018JD029245, 2019.

Xue, J., Griffith, S. M., Yu, X., Lau, A. K. H., and Yu, J. Z.: Effect of nitrate and sulfate relative abundance in $\mathrm{PM}_{2.5}$ on liquid water content explored through half-hourly observations of inorganic soluble aerosols at a polluted receptor site, Atmos. Environ., 99, 24-31, https://doi.org/10.1016/j.atmosenv.2014.09.049, 2014.

Zhong, H., Huang, R.-J., Duan, J., Lin, C., Gu, Y., Wang, Y., Li, Y. J., Zheng, Y., Chen, Q., Chen, Y., Dai, W. T., Ni, H. Y., Cao, J. J., Worsnop, D. R., Xu, W., Ovadnevaite, J., Ceburnis, D., and O'Dowd, C. D.: Seasonal variations in the sources of organic aerosol in Xi'an, Northwest China: The importance of biomass burning and secondary formation, Sci. Total. Environ., 737, 139666, https://doi.org/10.1016/j.scitotenv.2020.139666, 2020. 